\title{
Effect of ambient temperature and restricted feeding on the production of rabbit does and their kits ${ }^{\sharp}$
}

\author{
Zsolt Szendrö1* Zoltán Papp², Károly Kustos ${ }^{3}$ \\ ${ }^{1}$ Kaposvár University, Kaposvár, Hungary; ${ }^{2}$ University of Veterinary Medicine, Budapest, Hungary; \\ ${ }^{3}$ Szent István University, Gödöllő, Hungary
}

\begin{abstract}
Thirty-six lactating New Zealand White rabbit does were divided into 6 groups according to ambient temperature and feed intake. The does were kept at $20^{\circ} \mathrm{C}$ during pregnancy and at kindling, then they were put into climatic chambers at temperatures of $5,15,23$ or $30^{\circ} \mathrm{C}$. One part of the does were fed ad libitum $(5 \mathrm{~A}, 15 \mathrm{~A}, 23 \mathrm{~A}$ and $30 \mathrm{~A})$, two other groups were housed at $15^{\circ} \mathrm{C}$, but they received the same amount of pellet as the does' intake at $23^{\circ} \mathrm{C}$ or $30^{\circ} \mathrm{C}(15 / 23 \mathrm{R}$ and $15 / 30 \mathrm{R})$. The litter sizes were equalized to seven. The weight of does, milk production, feed intake and water intake were recorded daily. Heat stress reduced milk yield (148, 152, 150 and $106 \mathrm{~g} /$ day), feed intake $(287,279,260$ and $179 \mathrm{~g} /$ day) and water intake $(497,512,526$ and $428 \mathrm{~g} /$ day), but increased the water/feed ratio $(1.73,1.84,2.02$ and 2.39$)$ in the groups of $5 \mathrm{~A}, 15 \mathrm{~A}, 23 \mathrm{~A}$ and $30 \mathrm{~A}$, respectively. Body weight of does decreased at $23{ }^{\circ} \mathrm{C}$ and $30{ }^{\circ} \mathrm{C}$ by $5.6 \%$ and $8.5 \%$, respectively, compared to $15^{\circ} \mathrm{C}$. Comparing the groups of rabbits kept at $23{ }^{\circ} \mathrm{C}$ and $30^{\circ} \mathrm{C}$ fed ad libitum $(23 \mathrm{~A}$ and $30 \mathrm{~A})$ and the data obtained for groups of $15 / 23 \mathrm{R}$ and $15 / 30 \mathrm{R}$ it was observed that the milk yield decreased by $8.0 \%$ and $2.5 \%$, water intake increased by 8.6 and $13.3 \%$, and the feed/water ratio was higher by 0.18 and 0.18 , respectively. The effect of heat stress was less significant on kits than on does. It can be concluded that the high ambient temperature mainly affected the milk production through the reduction of feed intake.
\end{abstract}

Keywords: rabbit does, ambient temperature, restricted feeding, milk production, feed intake, water intake

\section{INTRODUCTION}

Recent weather reports show that the incidences of summer heat waves have been increasing with rising temperature. Probably the global warming will have severe impacts on the physiology and reproduction of mammals of both sexes (Takahashi, 2012). The effect of ambient temperature on animals' production has been investigated for a long time. Nowadays, due to the global warming, more and more researchers work on this area (Gill et al., 2010). The ambient temperature has influenced some physiological parameters of domestic rabbits (Boiti et al., 1992; Chiericato et al., 1997; Kalaba, 2012) and directly or indirectly influenced the feed intake, the reproduction and production performance (Stephan, 1980; Fernández-Carmona et al., 1995; Marai et al., 2002; Mousa-Balabel, 2004; Zeferino et al., 2011; Bakr et al., 2015).

${ }^{*}$ Note: This paper is a new evaluation of the results of a previous proceeding published on the 2 . International Conference on Rabbit Production in Hot Climates, Adana, Turkey (Szendrő et al., 1999).

\footnotetext{
*CORRESPONDING AUTHOR

Kaposvár University, Faculty of Agricultural and Environmental Sciences

$\triangle$ H-7400 Kaposvár, Guba S. str. 40., 正 +36-82-505-800

E-mail: szendro.zsolt@ke.hu
} 
Studies connected to milk production of rabbit does have been published since the 1960s. First results were summarized by Lebas (1975), later it was reviewed by Maertens et al. (2006). Connection between ambient temperature and milk production was discussed by Rafai and Papp (1984), FernándezCarmona et al. (1995, 2000), Askar and Ismail (2012). All these experiments showed significant decrease in milk production of does kept under high temperature condition.

The aim of the experiment was to investigate the direct and indirect effect of ambient temperature of $5{ }^{\circ} \mathrm{C}, 15^{\circ} \mathrm{C}, 23^{\circ} \mathrm{C}$ and $30^{\circ} \mathrm{C}$ on production of rabbit does and their kits. Beside the effect of temperature the performance of rabbits kept on $15^{\circ} \mathrm{C}$, but fed restricted on the levels of intake at $23^{\circ} \mathrm{C}$ or $30^{\circ} \mathrm{C}$ ambient temperature was also tested.

\section{MATERIAL AND METHODS}

The experiment was performed on multiparous New Zealand White does at the University of Veterinary Medicine (Hungary). The pregnant does $(n=36)$ were fed ad libitum at ambient temperature of $20{ }^{\circ} \mathrm{C}$ till parturition. The diet contained $11.4 \mathrm{MJ} \mathrm{DE} / \mathrm{kg}$ and $14 \%$ crude protein. Water was freely available. Six groups were formed, each group contained six does, and they were placed into climatic chambers. The following treatments were established:

5A: does kept on $5{ }^{\circ} \mathrm{C}$, fed ad libitum,

15A: does kept on $15{ }^{\circ} \mathrm{C}$, fed ad libitum,

23A: does kept on $23^{\circ} \mathrm{C}$, fed ad libitum,

30A: does kept on $30^{\circ} \mathrm{C}$, fed ad libitum,

15/23R: does kept on $15{ }^{\circ} \mathrm{C}$ and fed with daily amount of feed consumed by does in group $23 \mathrm{~A}$,

15/30R: does kept on $15{ }^{\circ} \mathrm{C}$ and fed with daily amount of feed consumed by does in group $30 \mathrm{~A}$.

At parturition the litter size was equalized to seven and the died kits were replaced with others out of the experiment with similar age and weight than the died ones. The daily milk production was measured by the difference in body weight of does immediately before and after nursing. The weight of does and litter, feed and water consumption were measured daily in the morning.

One-way ANOVA and T-test were applied for data evaluation. 


\section{RESULTS}

\section{Feed intake of does}

After parturition the feed intake increased in each group (Figure 1), however the consumption of group 30A decreased already after the second day of lactation. During the next weeks the feed consumption of $30 \mathrm{~A}$ does varied between 150 and $200 \mathrm{~g} /$ day. The consumption grew rapidly in the other groups and it reached higher level than $300 \mathrm{~g}$ /day between days 10 and 26 in $5 \mathrm{~A}$ and 15A groups, but it was lower (between 250 and $300 \mathrm{~g} /$ day) in 23A group. The average daily feed intake of $5 \mathrm{~A}, 15 \mathrm{~A}, 23 \mathrm{~A}$ and $30 \mathrm{~A}$ does was 287, 279,260 and $179 \mathrm{~g}$, respectively. The differences between $15 \mathrm{~A}$ and $23 \mathrm{~A}$, and between $15 \mathrm{~A}$ and $30 \mathrm{~A}$ group were $6.8 \%$ and $35.8 \%$, respectively. The consumption of groups $23 \mathrm{~A}$ and $15 / 23 \mathrm{R}$ and groups $30 \mathrm{~A}$ and $15 / 30 \mathrm{R}$ was similar, which corresponds to the experimental design.

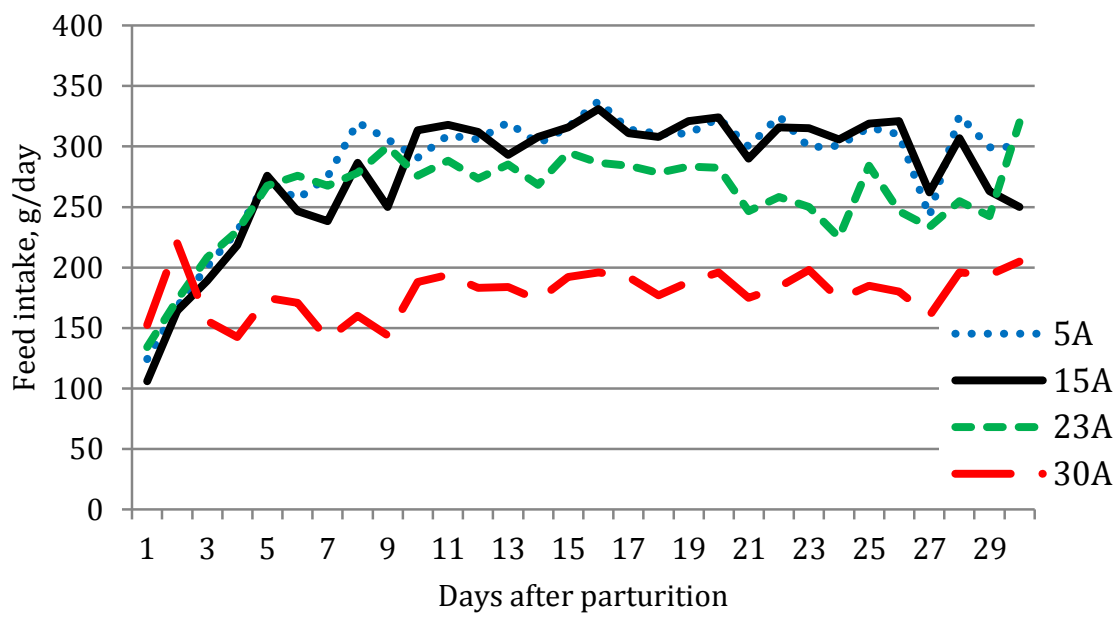

Figure 1: Effect of ambient temperature on feed intake of lactating does

\section{Water consumption of does}

In water consumption of experimental groups there were not as big differences as in feed consumption (Figure 2). Only the 30A does drank a little less water than does in the other groups. The average water consumption of 5A, 15A, 23A and 30A does was 497, 512, 526 and $428 \mathrm{~g}$ /day, respectively. Compared to $15 \mathrm{~A}$ group, the $5 \mathrm{~A}$ and $30 \mathrm{~A}$ does drank less water by $2.9 \%$ and $16.4 \%$, respectively, and $23 \mathrm{~A}$ does drank $2.7 \%$ more water. 


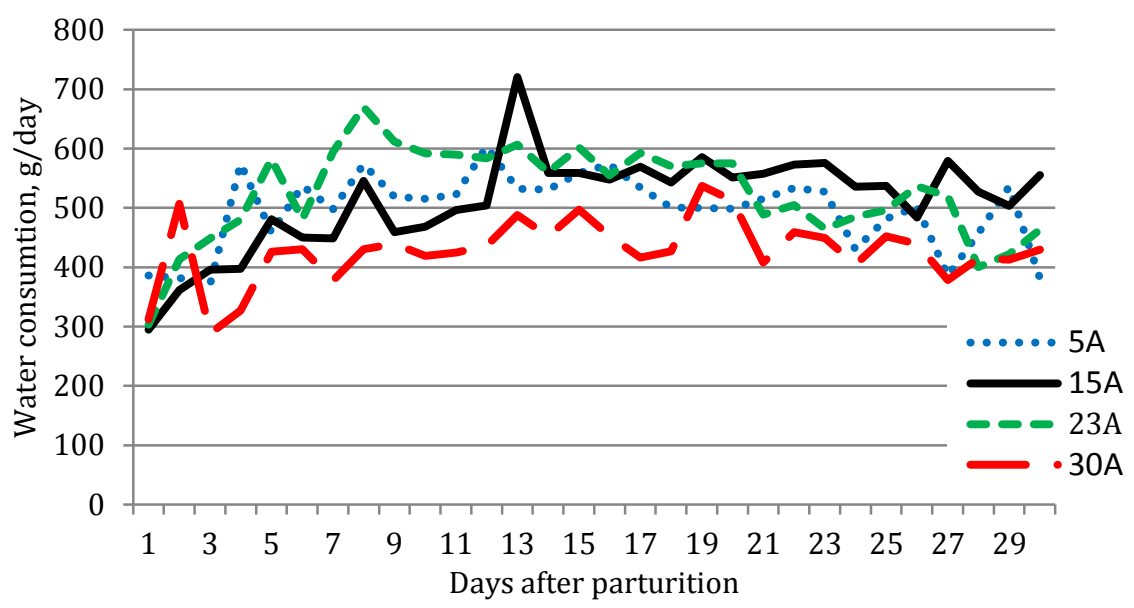

Figure 2: Effect of ambient temperature on water consumption of lactating does

The average water consumption of groups of 15/23R and 15/30R (571 and $428 \mathrm{~g} /$ day, respectively) was more than that of $23 \mathrm{~A}$ and $30 \mathrm{~A}$ does by $8.6 \%$ and $13.3 \%$, respectively (Figure 3).

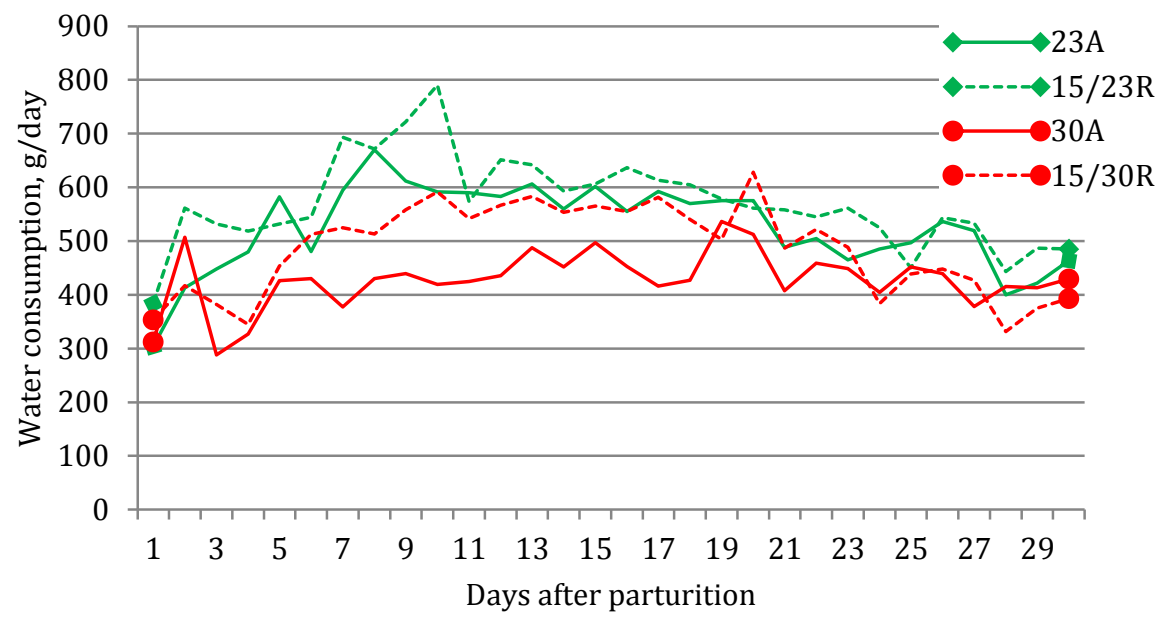

Figure 3: Effect of ambient temperature and feed restriction on water consumption of lactating does

The ratio of water per feed intake increased with increasing ambient temperature; they were 1.73, 1.84, 2.02 and 2.39 in groups of $5 \mathrm{~A}, 15 \mathrm{~A}, 23 \mathrm{~A}$ and 
$30 \mathrm{~A}$, respectively. Compared to ad libitum groups higher values were found when does were fed restricted: between groups of $23 \mathrm{~A}$ and $15 / 23 \mathrm{R}$ by 0.18 , and between groups of $30 \mathrm{~A}$ and $15 / 30 \mathrm{R}$ by 0.32 .

\section{Body weight of does}

Few days after parturition the body weight of does increased (Figure 4). It was the highest in groups 5A and 15A (about $3800 \mathrm{~g}$ ). The highest body weight of 23A does was measured at day 9 (3658 g) and it slowly declined till the end of the experiment (day 30) to 3470 g. The body weight of $30 \mathrm{~A}$ does decreased faster and reached the lowest value at day 27 (3368 g). The average body weights of $5 \mathrm{~A}, 15 \mathrm{~A}, 23 \mathrm{~A}$ and $30 \mathrm{~A}$ does were $3793,3785,3571$ and $3463 \mathrm{~g}$, respectively. Compared to $15 \mathrm{~A}$ group the body weight decreased by 5.7 and $8.5 \%$ in groups $23 \mathrm{~A}$ and $30 \mathrm{~A}$, respectively.

Significant differences were found between groups $23 \mathrm{~A}$ and $15 / 23 \mathrm{R}$, and between groups 30A and 15/30R at the end of the experiment (Figure 5). These differences between 23A (3470 g) and 15/23R (3653 g), and between $30 \mathrm{~A}$ (3387 g) and 15/30R (3519 g) groups were 3.9\% and 3.0\%, respectively, in favour of restricted does.

\section{Milk production}

The milk production curves of 5A, 15A and 23A does increased until day 20 of lactation with highest values of 201, 217 and $208 \mathrm{~g} /$ day, then it began to decline (Figure 6). Significantly lower milk production was measured in $30 \mathrm{~A}$ group with $130 \mathrm{~g} /$ day at day 20 . The average daily milk production of 5A, 15A and 23A does were similar (148, 152 and $150 \mathrm{~g} /$ day), however significantly lower production (by 29\%) was observed in 30A group (106 g/day).

The average daily milk production differed between $23 \mathrm{~A}$ and $15 / 23 \mathrm{R}$ groups (150 and $138 \mathrm{~g}$, respectively), while the difference between $30 \mathrm{~A}$ and 15/30R groups was inconsiderable (106 and $102 \mathrm{~g}$, respectively), however it depended on the stage of lactation (Figure 7). Higher milk production was found in 23A group than in 15/23R group during the whole lactation period, however 15/30R does produced more milk in the first half of lactation than $30 \mathrm{~A}$ does, while in the second half of lactation the order of the groups reversed, at day 30 of lactation the produced amounts of milk were $79 \mathrm{~g}$ and $52 \mathrm{~g}$ in groups of 30A and 15/30R, respectively.

\section{Feed consumption of kits}

The feed consumption of kits in groups 5A, 15A and 23A was similar (Figure 8 ) with a slight increasing tendency $(12.2,12.5$ and $12.6 \mathrm{~g}$, respectively), while significant lower consumption (9.93 g) was observed in 30A group. 
Significant differences were found between the ad libitum and restricted fed groups (Figure 9): the 23A kits consumed more feed than the 15/23R group (12.6 and $10.9 \mathrm{~g} /$ day, respectively), while 30A kits consumed less pellet than the kits in 15/30R group (9.9 and $12.5 \mathrm{~g}$ /day, respectively).

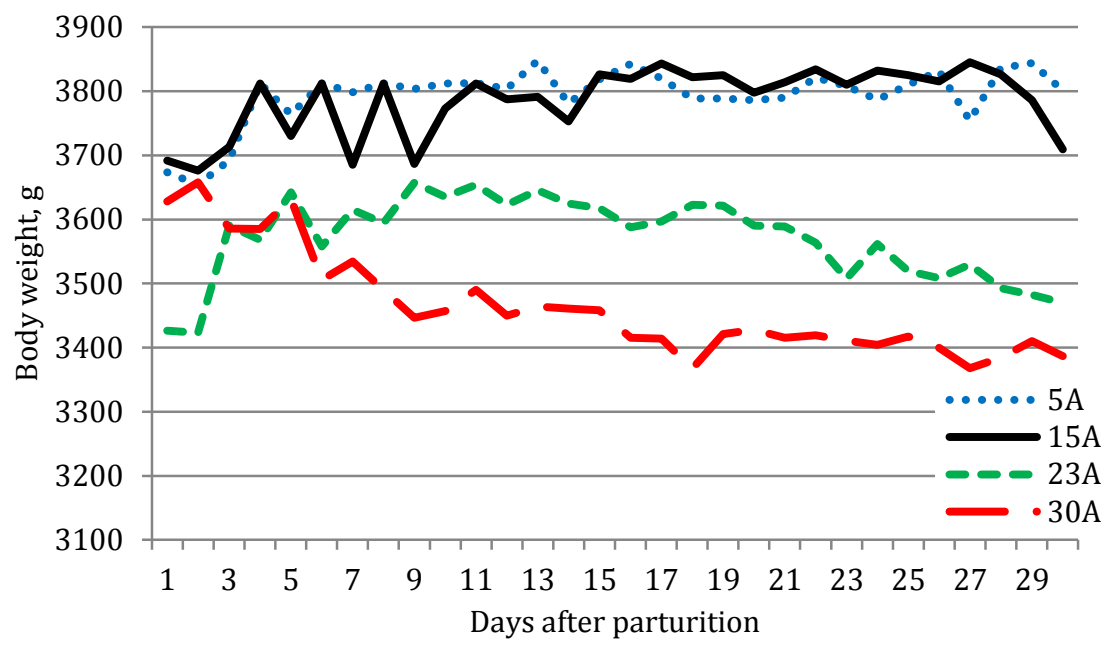

Figure 4: Effect of ambient temperature on body weight of lactating does

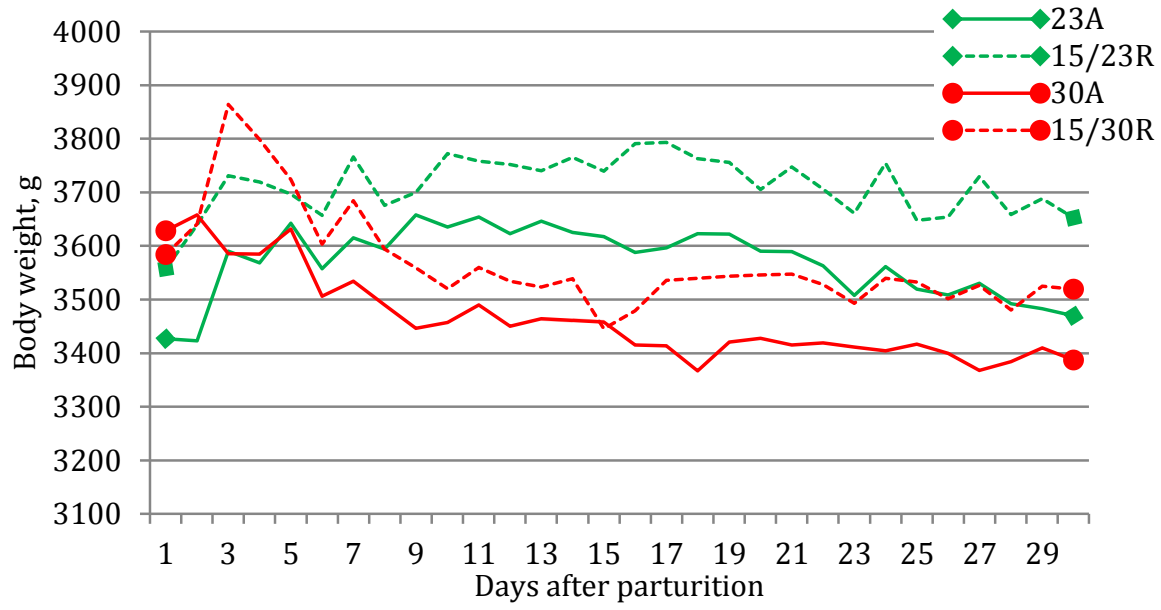

Figure 5: Effect of ambient temperature and feed restriction on body weight of lactating does 


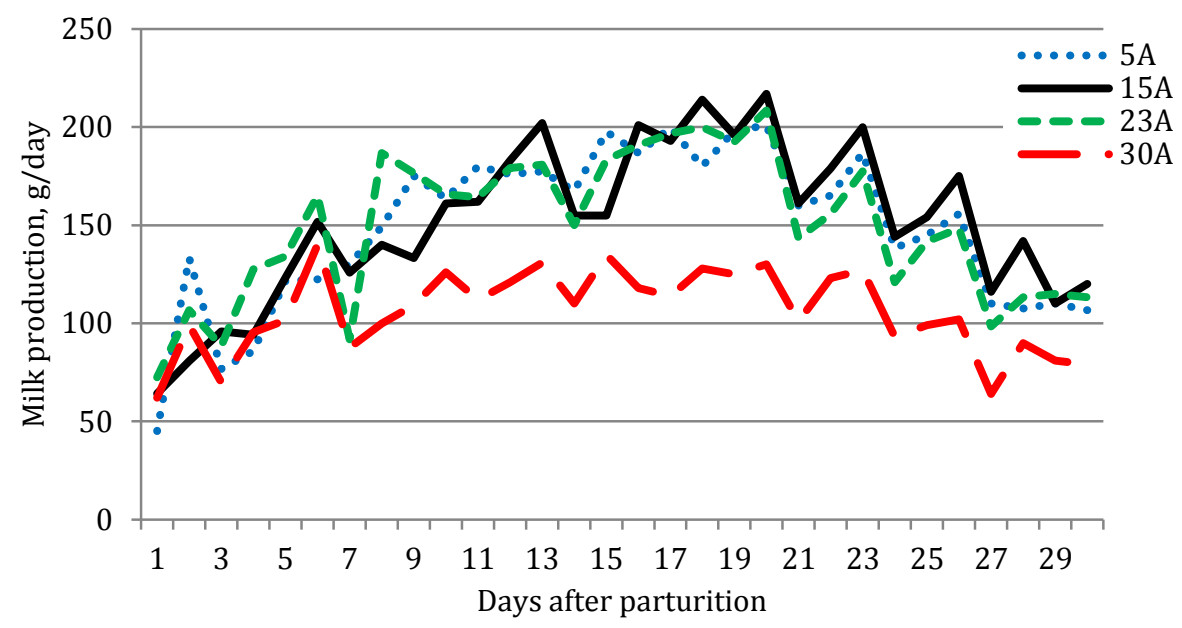

Figure 6: Effect of ambient temperature on daily milk production of does

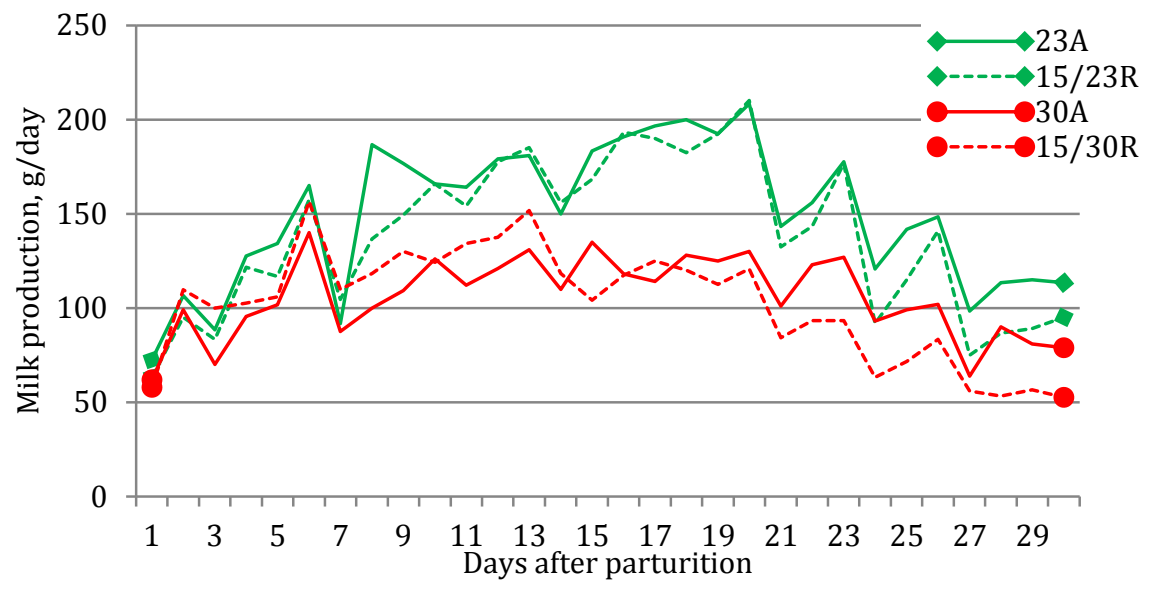

Figure 7: Effect of ambient temperature and feed restriction on daily milk production of does 


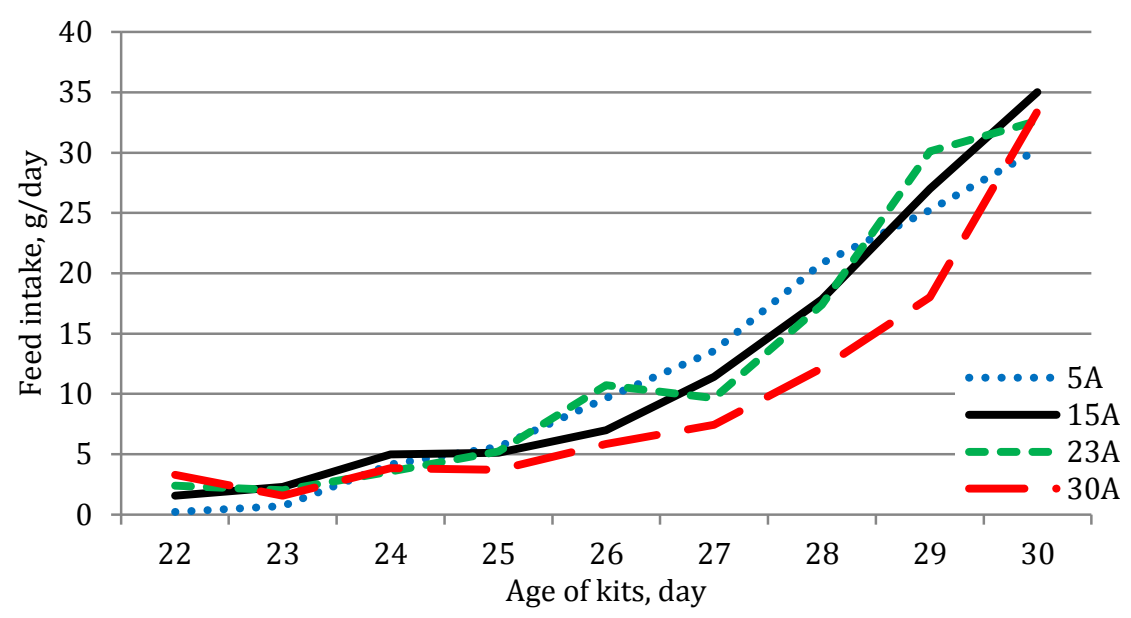

Figure 8: Effect of ambient temperature on feed consumption of kits

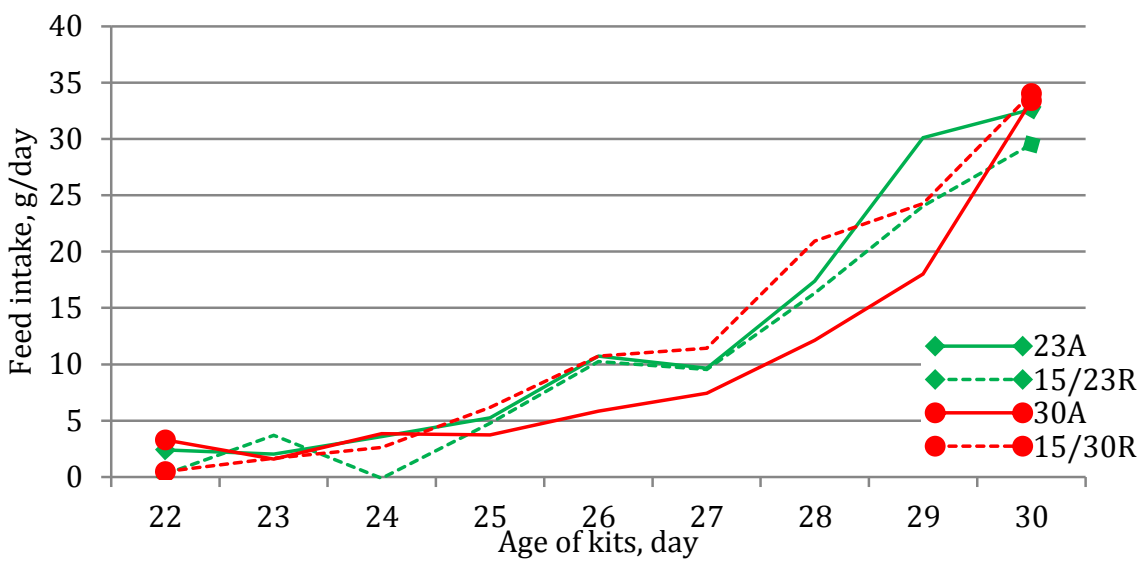

Figure 9: Effect of ambient temperature and feed restriction of rabbit does on feed consumption of kits

\section{Water consumption of suckling rabbits}

Kits in groups 5A and 15A drank similar amount of water (25.9 and $25.5 \mathrm{~g} /$ day, respectively). Rabbits in group 23A drank significantly higher amount of water between days 22 and 30 (36.6 g/day) (Figure10), while in 30A group kits drank more than double amount of water (74.2 g/group) than in $23 \mathrm{~A}$ group. 


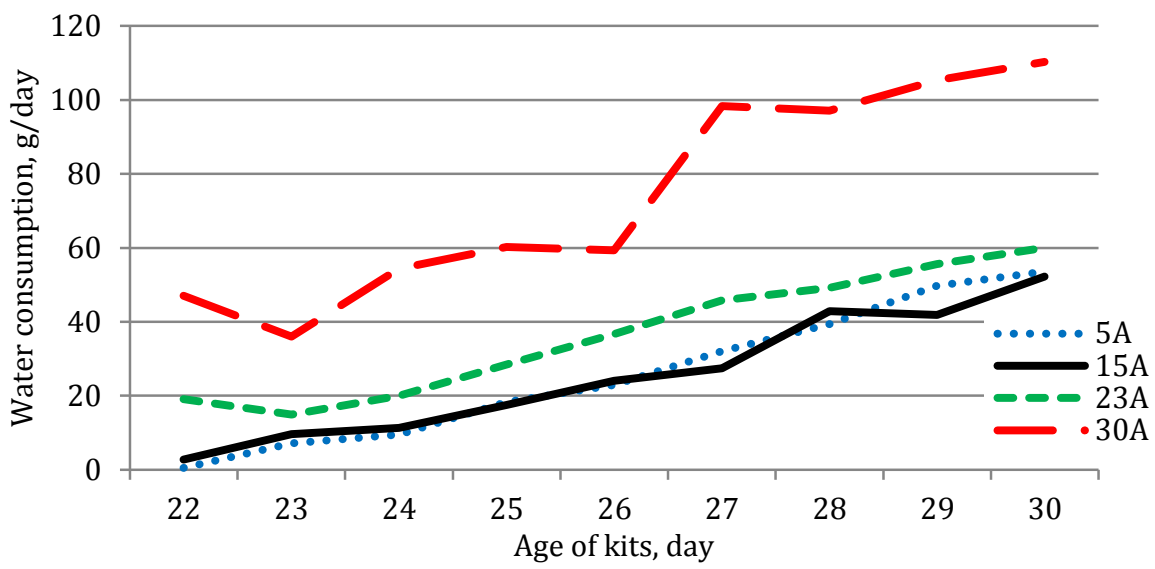

Figure 10: Effect of ambient temperature on water consumption of kits

The water consumption of restricted groups (15/23R and 15/30R) was the same (22.5 and $22.0 \mathrm{~g} /$ day, respectively), however it was significantly lower than that of the 23A and 30A kits (Figure 11).

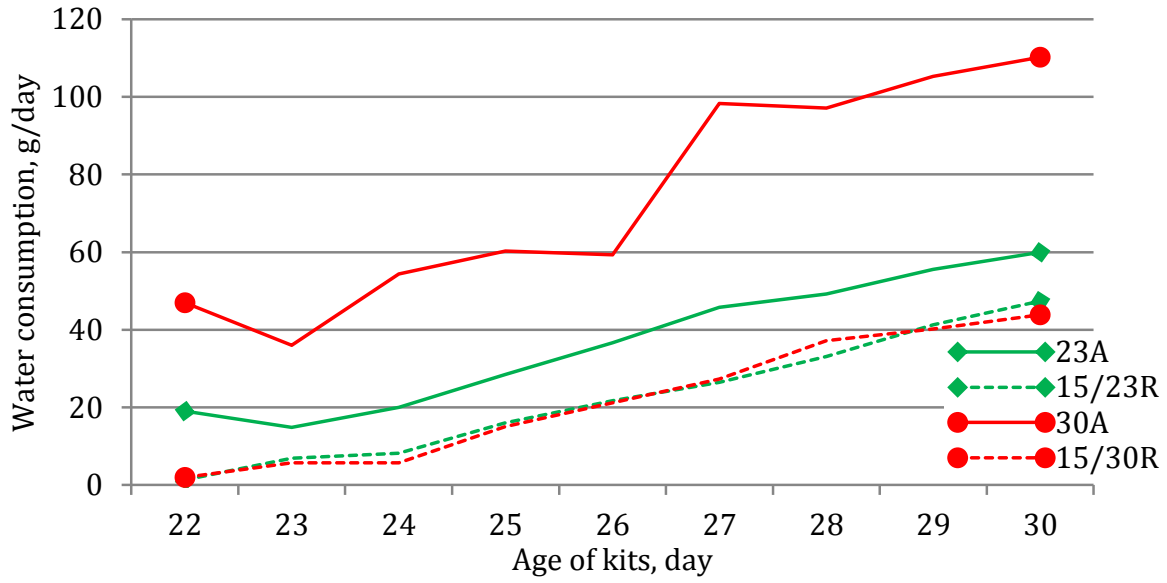

Figure 11: Effect of ambient temperature and feed restriction of rabbit does on water consumption of kits

\section{Litter weight}

Connection was observed between milk production of does and growth of litters. No significant differences were observed in litter weight till 9 days of 
age. From the time, when the milk production of group 30A was lagging behind the other groups, there was also a significant difference in litter weight (Figure 12 and 13).

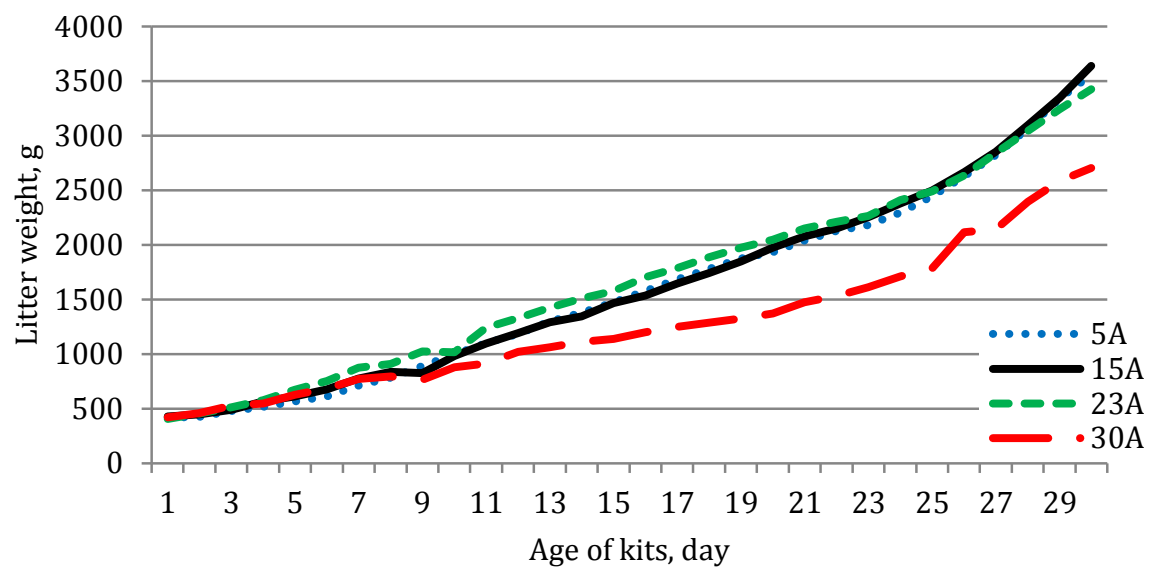

Figure 12: Effect of ambient temperature on litter weight

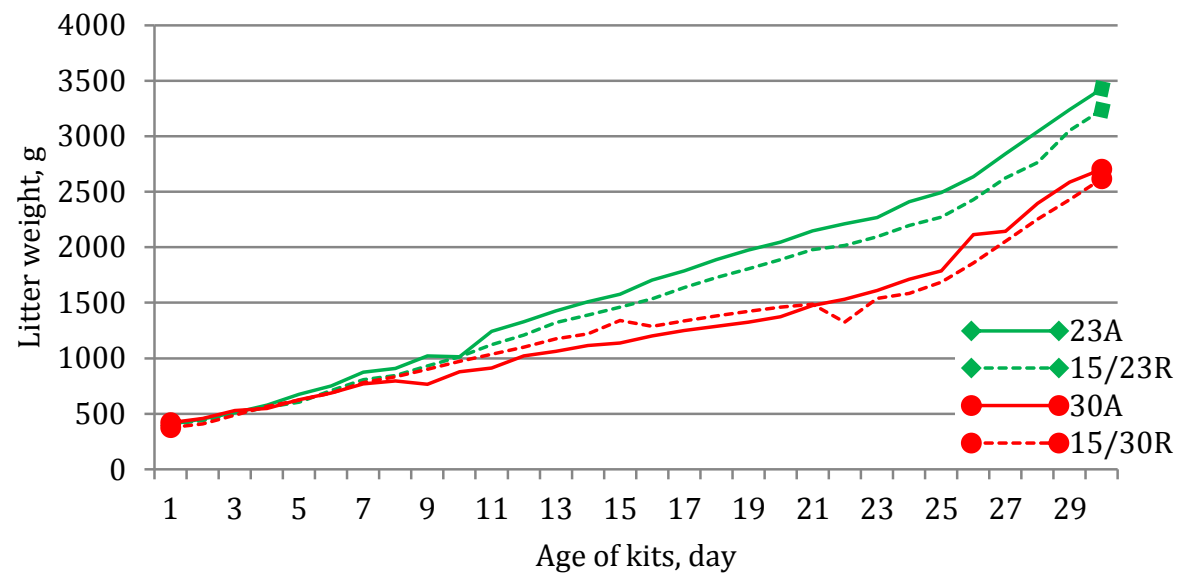

Figure 13: Effect of ambient temperature and feed restriction of rabbit does on litter weight 


\section{DISCUSSION}

Heat is one of the most important climatic factors, which may affect rabbit production in hot climates (tropics or hot summer). The environment is sometimes defined by the season of the year and its effects are evaluated. In hot climate or in summer, despite the high temperature during day, it is lower in the night, when the rabbits are more active and they consume more feed. Several times controlled environments (climatic chambers) are used. However, the ambient temperature could be the same in both cases, but in climatic chamber temperature can remain high for 24 hours. This is why the effect of high temperature is more significant if climatic chamber is used than under natural conditions. In the present experiment rabbits were kept in climatic chambers without any change of temperature throughout the experiment.

Rabbits are very sensitive to high ambient temperatures since they have few functional sweat glands limiting their ability in eliminating excess body heat (Maya-Soriano et al., 2015). As a homeothermic animal, they can regulate the heat input and output of their bodies using physical, morphological, biochemical, and behavioural processes (Marai and Habeeb, 1994).

\section{The performance of rabbit does}

Feed intake, body weight and milk production of does are in close connection with each other, therefore we evaluated them together.

Though $5{ }^{\circ} \mathrm{C}$ is lower than the optimal temperature for rabbits, it hardly affected the production of does, only slightly less water consumption was observed compared to the rabbits at $15^{\circ} \mathrm{C}$.

According to Marai and Habeeb (1994) and Verga et al. (2007) the ideal ambient temperature range should be $16-21^{\circ} \mathrm{C}$ for rabbit does. In case of high ambient temperature a decrease in feed intake is the most important reaction (Marai et al., 2002). Based on opinion of Mousa-Balabel (2004), when rabbits are exposed to high ambient temperature, there is an inhibition of the hypothalamic appetite centre, hence feed intake is reduced in order to diminish body heat production. The lower performance of does kept on warm or hot climates could be also in connection with the lower digestibility of diet; the digestibility coefficients of dry matter and crude protein declined by about $8 \%$ due to the heat stress (Marai et al., 2001).

In the present experiment the decreased feed intake led to a decline in body weight and milk production of does. It confirmes the results of Maertens and de Groote (1990), who evaluated the effect of high ambient temperature during 
short (1-week) period of lactation and reported 11\% decrease in feed intake and $9 \%$ in milk production. In accordance to findings of other authors (e.g. Simplicio et al., 1988; Fernández-Carmona et al., 1995) the high ambient temperature had a negative effect on the milk production. It seems that lactating does react very sensitive to higher ambient temperatures; because in the present experiment their feed intake declined at $23{ }^{\circ} \mathrm{C}$. However, we observed only a slight decline in milk production, but body weight of does decreased significantly. The experimental results of Rafai and Papp (1984) also showed that at $25^{\circ} \mathrm{C}$ a noticeable reduction in feed intake started, and subsequently milk yield, litter weight and doe weight were affected.

In the present experiment, the decrease in feed consumption and milk production were even more significant at $30^{\circ} \mathrm{C}$. Comparing the feed intake of lactating does in traditional building at $30{ }^{\circ} \mathrm{C}$, similarly to our result, a $34 \%$ decline was observed by Fernández-Carmona et al. (1995). In the experiment of Papp et al. (1983) body weight of does kept on $10^{\circ} \mathrm{C}$ and $15^{\circ} \mathrm{C}$ increased, at $23{ }^{\circ} \mathrm{C}$ remained unchanged, but at $30^{\circ} \mathrm{C}$ definitely decreased between days 6 and 29 of lactation. Fernández-Carmona et al. (1995) housed does at $30^{\circ} \mathrm{C}$ and observed 32\% lower milk yield. Rafai and Papp (1984) found a decrease of 7.7 $\mathrm{g}$ in milk yield per day with each centigrade above $20^{\circ} \mathrm{C}$; and it was the highest in the 3rd week of lactation. Bakr et al. (2015) compared two groups of does. One group was housed in comfort condition $\left(18-22^{\circ} \mathrm{C}\right)$ and in the other group Mediterranean summer was simulated $\left(24^{\circ} \mathrm{C}\right.$ at $08: 00 \mathrm{~h}$, increasing up to $29^{\circ} \mathrm{C}$ until $11: 00 \mathrm{~h}$; maintenance at $29^{\circ} \mathrm{C}$ to $31^{\circ} \mathrm{C}$ for $4 \mathrm{~h}$ and decreasing to about $24^{\circ} \mathrm{C}$ to $26^{\circ} \mathrm{C}$ around 17:00 h until 08:00 h of the following day). Under high ambient temperature the feed intake, body weight of does and weaning weight of kits decreased by $9.4 \%, 6.2 \%$ and $8 \%$, respectively, and no significant differences were found in water intake and milk production of does, because of fluctuation of heat during the day. Daily 8-hour high heat stress $\left(37^{\circ} \mathrm{C}\right)$ resulted strong negative effect on milk yield (24-29\%) compared to group reared in comfort condition (Askar and El Ismail, 2012). Ayyat et al. (1995) also observed lower milk yield in hot season (summer) than in winter or in spring.

The design of experiment (feed restriction of does at $15^{\circ} \mathrm{C}$ for similar levels than the does consumed at temperature of $23^{\circ} \mathrm{C}$ and $30^{\circ} \mathrm{C}$ ) gave opportunity to evaluate the effect of high ambient temperature $\left(23^{\circ} \mathrm{C}\right.$ and $\left.30^{\circ} \mathrm{C}\right)$ and the lower feed intake at the same temperature without heat stress.

Comparing the differences between the average body weights of $15 \mathrm{~A}$ and $23 \mathrm{~A}$ groups (214 g), and between $15 \mathrm{~A}$ and $15 / 23 \mathrm{R}$ groups (73 g) demonstrated that $34 \%$ of the weight loss at $23{ }^{\circ} \mathrm{C}$ was caused by the lower feed intake. Analyzing the difference in feed intake between $15^{\circ} \mathrm{C}$ and $30{ }^{\circ} \mathrm{C}$, 
$68 \%$ of the weight loss at $30^{\circ} \mathrm{C}$ was caused by the lower feed intake. These results show the role of lower feed intake and the physiological factors on weight loss caused by high ambient temperature.

Due to the similarity in average milk production of the groups of $30 \mathrm{~A}$ and 23/30 R during the whole lactation, and because the milk production was higher in 23A group than in 15/23R does at the end of lactation, it can be stated that the effect of high ambient temperature was mainly based on the lower feed intake. It seems that the change in milk production was independent of the body weight loss. Probably, rabbit does mobilized the fat and protein of body for milk production. This finding is in accordance with Parigi-Bini et al. (1992), Xiccato (1996), Feugier and Fortun-Lamothe (2006), Xiccato and Trocino (2010).

Rabbit is largely dependent on respiratory evaporation for regulation of body temperature in hot conditions. The significance of the increase of respiration is that it enables the rabbit to dissipate heat by vaporising high moisture through the respiratory air, which accounts for about $30 \%$ of the total heat dissipation (Fayez et al., 1994). This is why the respiration rate increased from 69 to 190 breaths per minute when the ambient temperature raised from 18 to $33^{\circ} \mathrm{C}$ (Johnson et al., 1957). The high water consumption in the hot period helps the animal to increase the heat loss through water respiratory vaporization $(B a d r, 2015)$. Rabbits need to make up for water loss. Stephan (1980) recorded $45 \%$ increase in water intake of growing rabbits at $38^{\circ} \mathrm{C}$ compared to $18^{\circ} \mathrm{C}$. Similarly to our results, in the experiment of Marai et al. (2001), the water intake and the water/feed ratio of does significantly increased. In the present experiment the water to feed ratio increased from 1.84 to 2.39 between temperatures $15^{\circ} \mathrm{C}$ and $30^{\circ} \mathrm{C}$.

\section{Kits' performance}

The effect of high ambient temperature on kits is different from the adult rabbits, because they born hairless, so their optimal ambient temperature is higher, around $38^{\circ} \mathrm{C}$ at birth and $30^{\circ} \mathrm{C}$ at 14 days of age (Hull et al., 1986). This is why $23^{\circ} \mathrm{C}$ could be warm for does, but at the same time it could be cold for kits. We have to take into consideration that the performance of kits is affected indirectly by the effect of heat on their mother and directly on kits.

There were not any differences in feed intake of kits and litter weight when they were reared at $5{ }^{\circ} \mathrm{C}$ or $15{ }^{\circ} \mathrm{C}$, however it was lower than at the optimal temperature. 
Solid feed intake of kits starts at about 18 to 21 days of age (Maertens and De Groote, 1990). The degree of increment in feed intake of kits depends on milk production of does (milk intake of kits). There were only slight differences in feed intake between groups of $5 \mathrm{~A}, 15 \mathrm{~A}$ and $23 \mathrm{~A}$, which showed that the effect of ambient temperature was inconsiderable till $23{ }^{\circ} \mathrm{C}$, but marked decline was observed in group 30A. It was confirmed by the difference between the 30A and 15/30R groups, which also showed the effect of high ambient temperature on feed intake of kits. It seems that the effect of ambient temperature on kits' feed consumption was much less than on their mothers.

Growth of kits mainly depends on the milk production of does, the milk intake of kits (Maertens et al., 2006) and their own solid feed intake. In the present experiment the difference between 30A and the other groups started at about 10 days of lactation and it increased till kits started to consume solid feed (at about 21 days of age), which was caused by the lower milk production of 30A does. The difference remained similar till weaning, which showed that the lower feed intake of kits was mainly related to the smaller weight, the lower requirement of maintenance. Ayyat et al. (1995) described that parallel with milk yield the litter weight was also low in summer. Due to the heat stress, lower litter weight at weaning was observed by Marai et al. (2001). MarcoJiménez et al. (2017) received 14\% difference in individual body weight of kits at 30 days of age between temperatures of $14-20^{\circ} \mathrm{C}$ and $25-36^{\circ} \mathrm{C}$. Piles et al. (2013) proved that the individual weaning weight decreased by $14 \mathrm{~g}$ per each centigrade when temperature was higher than $21^{\circ} \mathrm{C}$.

Results show that the water intake of kits depends more on ambient temperature than that on feed intake. The kits in 23A group drank more water than the 15A kits, but 30A kits drank double amount of water than 23A kits. The same result was shown by the ratios of water/feed consumption, which were a little bit higher than 2 in groups $5 \mathrm{~A}$ and $15 \mathrm{~A}$, but it was significantly higher in 23A kits (2.90) and it was much higher in A30 group (7.48). According to these results the water intake could be independent of the mother, it depends on the ambient temperature, and the respiration rate of kits could be high at higher ambient temperature to lose the extra heat.

\section{CONCLUSIONS}

Based on the results it can be stated that:

- housing of rabbit does and their kits at $5^{\circ} \mathrm{C}$ hardly modify their production compared to the optimal $\left(15^{\circ} \mathrm{C}\right)$ ambient temperature;

- rearing rabbit does at $23^{\circ} \mathrm{C}$, their feed intake decrease non-significantly 10 days after parturition compared to rabbits 5 and at $15^{\circ} \mathrm{C}$. However, there 
is a significant decrease in body weight, while the milk production is not affected;

- at $30^{\circ} \mathrm{C}$ the heat stress is very high, rabbit does consume much less pellet, their weight and milk production is much more less than that of rabbits at 5 , 15 and $23{ }^{\circ} \mathrm{C} ; 68 \%$ of the weight loss was based on the lower feed intake, in case of milk production mainly the lower feed intake was responsible for the low milking level;

- in kits the main effect of high ambient temperature was the high water intake and because of the lower milk and feed intake their weight decreased significantly.

\section{ACKNOWLEDGEMENTS}

Writing the paper was supported by project of GINOP-2.3.4-15-2016-00005, and it was also supported by the EFOP-3.6.3-VEKOP-16-2017-00008 project. The project is co-financed by the European Union and the European Social Fund.

\section{REFERENCES}

Askar A.A., Ismail I.El. 2012. Impact of heat stress exposure on some reproductive and physiological traits of rabbit does. Egypt. J. Anim. Prod., 49, 151-159.

Ayyat M.S., Marai I.F.M., El-Sayiad Gh.A. 1995. Genetic and non-genetic factors affecting milk production and preweaning litter traits of New Zealand White does under Egyptian conditions. World Rabbit Sci., 3, 119-124. DOI: 10.4995/wrs.1995.250

Badr M.M.A. 2015. Effect of feeding time and vitamin C levels on performance of rabbit does during the mild and hot seasons in Egypt. Nat. Sci., 13, 25-30.

Bakr H.M., Tusell L., Rafel O., Terré M., Sánchez P.J., Piles M. 2015. Lactating performance, water and feed consumption of rabbit does reared under a Mediterranean summer circadian cycle of temperature v. comfort temperature conditions. Animal, 9, 1203-1209. DOI: $10.1017 / s 1751731114003310$

Boiti C., Chiericato G.M., Filotto U., Canali C., 1992. Effects of high environmental temperature on plasma testosterone, cortisol, T3 and T4 levels in the growing rabbit. J. Appl. Rabbit Res., 15.447-455.

Chiericato M.G., Rizzi C., Boiti C., Canali C., Rostellato V. 1997. Endocrine response of hybrid rabbits of different ages and under two environmental temperature conditions. Tropicultura, 15, 22-26.

Fayez I., Marai M., Alnaimy A., Habeeb M. 1994. Thermoregulation in rabbits. Cahiers Options Méditerranéennes; n. 8, 33-41.

Fernández-Carmona J., Cervera C., Sabater C., Blas E. 1995. Effect of diet composition on the production of rabbit breeding does housed in a traditional building and at $30^{\circ} \mathrm{C}$. Anim. Feed Sci. Techn., 52, 289-297. DOI: 10.1016/0377-8401(94)00715-1

Fernández-Carmona J., Santiago S., Alqedra I., Cervera C., Pascual J.J., 2000. Effect of lucerne-based diets on the reproductive performance of rabbit does at high environmental temperatures. In Proc.: 7th World Rabbit Congress, Valencia, Spain, C, 203-208.

Feugier A., Fortun-Lamothe L. 2006. Extensive reproductive rhythm and early weaning improve body condition and fertility of rabbit does. Anim. Res., 55, 459-470. DOI: 10.1051 /animres:2006025

Gill M., Smith P., Wilkinson M.J. 2010. Mitigating climate change: the role of domestic livestock. Animal, 4, 323-333. DOI: $10.1017 / s 1751731109004662$ 
Hull D., Hull J., Vinter J. 1986. The preferred environmental temperature of newborn rabbits. Biol. Neonate, 50, 323-330. DOI: $\underline{10.1159 / 000242616}$

Johnson H.D., Ragasdale A.C., Eheng C.S. 1957. Influence of constant environmental temperatures on growth responses and physiological reactions of rabbits and cattle. Mo. Agric. Exp. Sta. Res. Bull., No. 648.

Kalaba M.Z. 2012. Physiological response and stress indicators of California rabbits under intensive condition in Egypt. Asian J. Poultry Sci., 6, 65-78. DOI: 10.3923/ajpsaj.2012.65.78

Lebas F. 1975. Le lapin de chair, ses besoins nutritionnels et son alimentation pratique. ITAVI, Paris, 50 p.

Maertens L., de Groote G. 1990. Comparison of feed intake and milk yield of does under normal and high ambient temperature. J. Appl. Rabbit Res., 13, 159-162.

Maertens L., Lebas F., Szendrő Zs. 2006. Rabbit milk: A review of quantity, quality and non-dietary affecting factors. World Rabbit Sci., 14, 205-230. DOI: 10.4995/wrs.2006.565

Marai I.F.M., Habeeb A.A.M. 1994. Thermoregulation in rabbits. Options Méditerranéennes, 8, 33-41.

Marai M.F.I., Ayyat M.S., Abd El-Monem M.U. 2001. Growth performance and reproductive traits at first parity of New Zealand White female rabbit as affected by heat stress and its alleviation under Egyptian Conditions. Tropical Anim. Health Prod., 33, 451-462.

Marai M.F.I., Habeeb H.A.A., Gad E.A. 2002. Rabbits' productive, reproductive and physiological performance traits as affected by heat stress: a review. Livest. Prod. Sci., 78, 71-90. DOI: 10.1016/s03016226(02)00091-X

Marco-Jiménez F., García-Diego F.J., Vicente J.S. 2017. Effect of gestational and lactational exposure to heat stress on performance in rabbits. World Rabbit Sci., 25, 17-25. DOI: 10.4995/wrs.2017.5728

Maya-Soriano M.J., Taberner E., Sabes-Alsina M., Ramon J., Rafel O., Tusell L., Piles M., Lopez-Bejar M. 2015. Daily exposure to summer temperatures affects the motile subpopulation structure of epididymal sperm cells but not male fertility in an in vivo rabbit model. Theriogenology, 84, 384389. DOI: 10.1016/j.theriogenology.2015.03.033

Mousa-Balabel M.T. 2004. Effect of heat stress on New Zealand White rabbits' behaviour and performance. Minufiya Vet. J., 3, 125-134.

Papp Z., Kovács F., Rafai P. 1983. Impact of the climatic environment on large-scale rabbit farm. II. Effect of environmental temperature on the milk production of does and on the trend of losses throughout the suckling age. MÁL, 38. 2. 115-120.

Parigi-Bini R., Xiccato G., Cinetio M., Dalle Zotte A., 1992. Energy and protein utilization and partition in rabbit does concurrently pregnant and lactating. Anim. Prod., 55, 153-162. DOI: $\underline{10.1017 / s 0003356100037387}$

Piles M., Tusell L., Rafel O., Ramon J., Sánchez P.J. 2013. Effect of heat intensity and persistency on prolificacy and preweaning kit growth at different stages of the rabbit production cycle. J. Anim. Sci., 91, 633-643. DOI: 10.2527/jas.2012-5455

Rafai P., Papp Z. 1984. Temperature requirement of does for optimal performance. Arch. Exper. Vet. Med., Leipzig, 38, 450-457.

Simplicio J.B., Fernandez C. J., Cervera C. 1988. The effect of a high ambient temperature on the reproductive response of the commercial doe rabbit. Proc. 4th World Rabbit Congress, Budapest, Hungary, Vol. 3, 36-41.

Stephan E. 1980. The influence of environmental temperatures on meat rabbits of different breeds. Commercial Rabbit. 8, 12-15.

Szendrő Zs., Papp Z., Kustos K. 1999. Effect of environmental temperature and restricted feeding on production of rabbit does. 2. International Conference on Rabbit Production in Hot Climates, Adana, Turkey, 11-17.

Takahashi M. 2012. Heat stress on reproductive function and fertility in mammals. Reprod. Med. Biol., 11, 37-47. DOI: $\underline{10.1007 / s 12522-011-0105-6}$ 
Verga M., Luzi F., Carenzi C., 2007. Effects of husbandry and management systems on physiology and behaviour of farmed and laboratory rabbits. Horm. Behav., 52, 122-129. DOI: 10.1016/j.yhbeh.2007.03.024

Xiccato G., 1996. Nutrition of lactating does. In: 6th World Rabbit Congress, Toulouse, France, 1, 29-47.

Xiccato G., Trocino A. 2010. Energy and protein metabolism and requirements. In: De Blas C., Wiseman J. (Eds), The Nutrition of the Rabbit, CABI Publishing, CAB International, Wallingford, UK, Cambridge, USA, 83-118.

Zeferino P.C., Moura T.M.A.S.A., Fernandes S., Kanayama S.J., Scapinello C., Sartori R.J. 2011. Genetic group $\times$ ambient temperature interaction effects on physiological responses and growth performance of rabbits. Livest. Sci., 140, 177-183. DOI: 10.1016/j.livsci.2011.03.027 